\title{
Surveying the topography and examining the quality of the machined surface of selected hardened steels in the milling process
}

\author{
Jan Duplak*, Darina Duplakova****, Michal Hatala*, Svetlana Radchenko* and Enes Sukic** \\ *Faculty of Manufacturing Technologies with a seat in Presov, Technical University of Kosice, Bayerova 1, 08001 Presov, Slovakia \\ **Faculty of Information Technology and Engineering (FITI), University Union-Nikola Tesla, Jurija Gagarina 149a, 11070 Belgrade, Serbia \\ ***Corresponding Author: darina.duplakova@tuke.sk
}

Submitted: 18/12/2019

Revised: $11 / 11 / 2020$

Accepted: 17/11/2020

\begin{abstract}
The article deals with the surface roughness examination of three selected hard materials, that is, K100, $100 \mathrm{CrMnMo} 7$, and $16 \mathrm{MnCr} 5$, all with a defined hardness of HRC 60 . The individual materials were machined using sintered carbide and cermet cutting materials with $\mathrm{TiCN}$ and $\mathrm{TiN}+\mathrm{TiCN}+\mathrm{Al}_{2} \mathrm{O}_{3}$ coatings. The research resided in the realization of three experiments. These experiments were carried out by three alternatives differing in the setting of basic cutting parameters. The experimental procedure was realized by the simulation method and direct contact measurement method of surface roughness. From the overall technical evaluation described in the practical part of the article, for the primarily observed parameter, the surface roughness, the least suitable values were obtained in the evaluation of the material from experiment No. 1-K100 with hardness HRC60. The experiments realized and the results achieved show that the machining of tool steels and other superhard materials requires special cutting tools, machines, and the use of progressive technologies, to ensure the production of a dimensionally and qualitatively shaped functional component.
\end{abstract}

Keywords: Surface roughness; Topography; K100; 100CrMnMo7; 16MnCr5.

\section{INTRODUCTION}

A necessary part of an efficient production process is to meet the basic parameters monitored. The competition that has been trending in the mechanical engineering sector in recent years, in manufacturing, does not only take dimensional and geometrical tolerances, but also take the resulting surface quality as a necessary part of the correct product (Valíček et al., 2016; Krolczyk et al., 2016). In the manufacturing process, not only dimensional and geometrical accuracy, but also the overall surface quality and design play an important role. An increased view of overall surface quality forces scientists to examine the surface quality and topography, machinability, optimization of cutting parameters resulting therefrom, and all partial factors that can modify measured outputs in an elemental or global perspective. In spite of the efforts of scientific practice, the relations between the topography of the machined surface and the technological system (machine, tool, workpiece, and cutting parameters) can be obtained only in the degree of probability, with the possibility of generalizing in a range of 82-87\% of all alternatives (Knapčíková, 2013; Knežo et al., 2016). The present article is aimed at surveying the topography and the examination of the quality of the machined surface of selected hardened steels in the milling process of steels, which are among the most used technical materials in the automotive industry and robotics due to their chemical composition and mechanical and physical properties (Michalik et al., 2017; Mital'ová et al., 2016). 
From the point of view of production, it is extremely important to know the technological processes, in which new surfaces of parts are created. If the technological process is well known, it is possible to understand the nature and properties of the surface that has been produced through some of the production technologies. because of the information provided by the surface of the machined material, it is then possible to optimize or innovate the production process itself (Lehocká et al., 2017).

There are many surface roughness parameters that can be used to analyze a surface. Particular parameters are classified and described in ISO 4287:1997-Geometrical Product Specifications (GPS).

Several basic factors that are shown through the Ishikawa diagram (Fig. 1) influence the above parameters defining surface roughness in the manufacturing process. To ensure the required quality of the final product, it is essential to take into account and control all these factors during manufacture (Benardos and Vosnaikos, 2013).

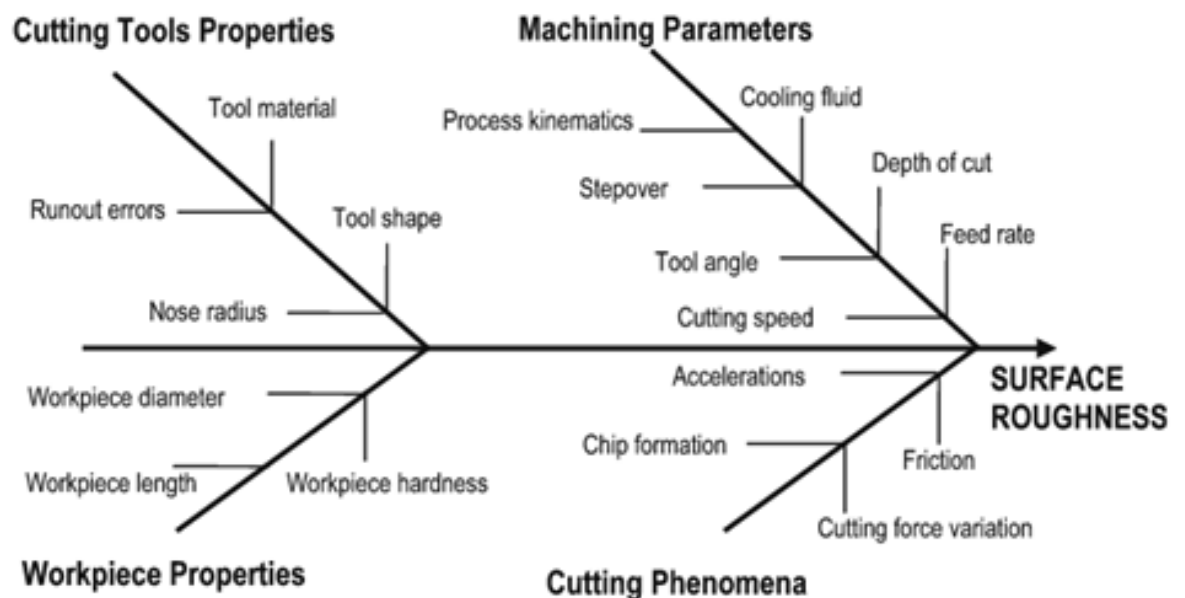

Figure 1. Ishikawa diagram of parameters that affect the surface roughness (Benardos and Vosnaikos, 2013).

Several experts in the world deal with the problem of surface roughness determination during machining of superhard materials. The relationship between machined surface integrity and cutting parameters of 4340 alloy steel was presented by authors Hassanpour et al. (2016). During this experiments, there were used the minimum quantity lubricant in the hard milling. In 2016, during the micromilling process, these same authors described the effects of various cutting conditions on the integrity of surface, material Ti6Al4V (Hassanpour et al., 2016). The authors Agrawal, Goel, Rashid, and Price (2015) present an approach of modeling 39 comprehensive experimental trials (during the hard turning) to predict the machined surface roughness of $69 \mathrm{HRC}$ steel with a cutting tool from CBN. During the turning, in the research article by authors Elmunafi et al. (2015), the Castrol oil was selected as a cutting fluid of hardened stainless steel. The minimum quantity lubrication (MQL) was used at various cutting speeds and feeds during this turning. The machining responses were surface roughness, tool life, and cutting forces. In the next research, the study about the investigation on the AISI H13 steel turning is presented with ceramic tools: wiper and conventional. These experiments were performed to evaluate tool wear and surface roughness evolution. On the surface roughness, it was evaluated an influence of the flank wear too (Ferreira et al., 2016). Most authors devote their research to the evaluation of hard materials surfaces after machining by turning technology (Aouici, et al., 2016; Rashid, et al., 2016; Sharma et al., 2015; Aouici et al., 2011; Khamel et al., 2012; Čepová et al., 2016). This research is focused on the evaluation of surfaces of superhard materials after machining by milling technology. 


\section{MATERIALS AND METHODS}

In industry, the roughness parameter used is the average roughness. This roughness Ra can be calculated using the equation (Ståhl et al., 2011):

$$
R a=\frac{1}{L_{m}} \cdot \int_{0}^{L_{m}}|y| \cdot d x
$$

where

$\mathrm{L}_{\mathrm{m}}$ - measuring length.

This parameter Ra was determined using the Handysurf E-35A, which is designed to measure surface roughness. To measure the surface roughness, a direct touch measurement method was used in the research, a method that is based on the principle of measuring touch motion on the surface of the machined part with a small radius of the tip. This tip is part of an inductive or piezoelectric sensor. Surface movement is motoric.

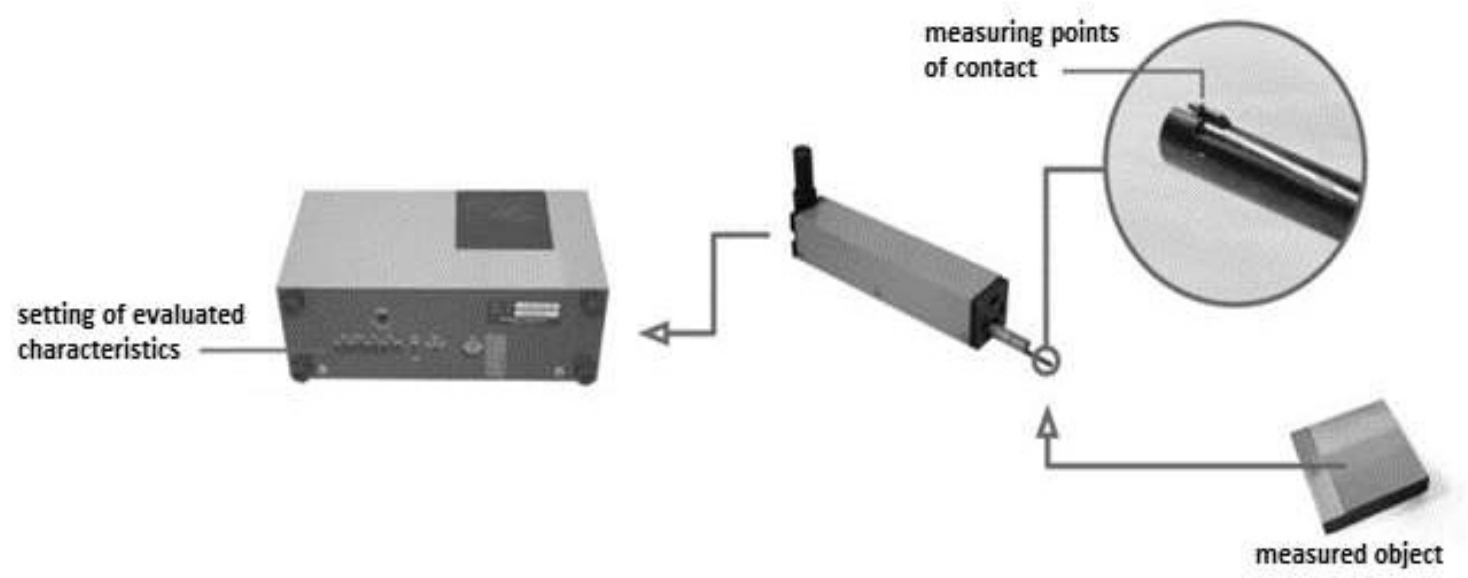

Figure 2. Schematic representation of touch surface roughness measurement.

Three materials were used to perform the experiments: K100, 16MnCr5 and 100CrMnMo7, all with HRC 60 hardness. The basic characteristic of K100 ledeburite chrome steel is the high resistance to wear and tear as well as resistance to dimensional changes. This material is most often used to produce punches in the clock industry, and highstressed components in electrical engineering. The second material used in the experiments was $100 \mathrm{CrMnMo} 7$, which is classified as steel for the production of rolling bearings. The last of the materials used to perform the experiments was $16 \mathrm{MnCr} 5$ with hardness $\mathrm{HRC} 60$, which is characterized as cementing steel, used for medium-stressed parts of motor vehicles and machines. The chemical composition of materials is shown in table 1.

Table 1. Chemical composition of materials.

\begin{tabular}{|l|c|c|c|c|c|c|c|}
\hline & C [\%] & Mn [\%] & Si [\%] & Cr [\%] & Mo [\%] & P [\%] & S [\%] \\
\hline K100 & 2.00 & 0.30 & 0.25 & 11.50 & - & - & - \\
\hline $\mathbf{1 0 0 C r M n M o 7 ~}$ & $0.90-1.05$ & $0.60-0.90$ & $0.20-0.40$ & $1.65-1.95$ & $0.20-0.40$ & 0.030 & 0.025 \\
\hline $\mathbf{1 6 M n C r 5}$ & $0.14-0.19$ & $1.00-1.30$ & - & $0.80-1.10$ & - & $\begin{array}{c}\max . \\
0.035\end{array}$ & $\begin{array}{l}\max . \\
0.035\end{array}$ \\
\hline
\end{tabular}


In order to ensure relevant results, the following measures (Fig. 3) were used for interoperational and output control:

- Handysurf E-35A measuring instrument measures surface roughness

- Renishaw OMP40 probe provides interoperation control

- Thome CMM Rapid 3D measuring device provides output control
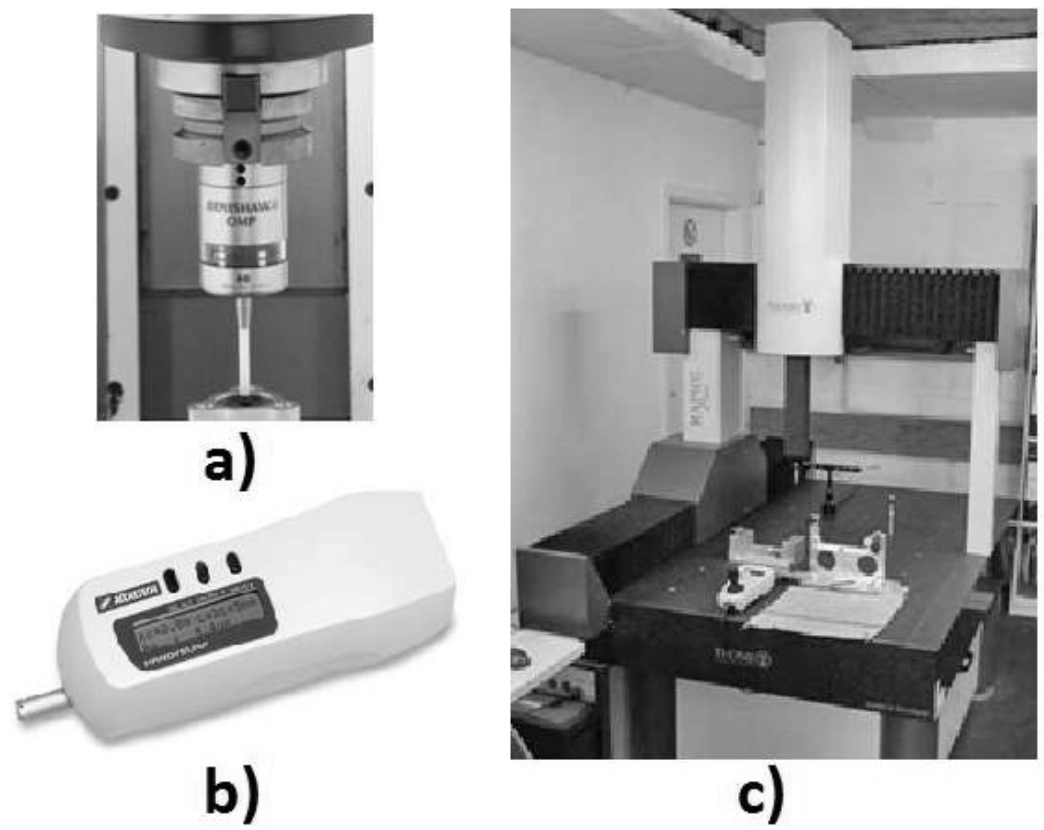

Figure 3. Measurement devices: a) Renishaw OMP40 b) Handysurf E-35A c) Thome CMM Rapid.

Individual experiments were carried out on a CNC using several types of tools (Fig. 4). An overview of the tools used with their basic parameters is given in the following table.

Table 2. Technical specification of tools used.

\begin{tabular}{|l|c|c|c|}
\hline Tools & $\begin{array}{c}\text { Diameter } \\
{[\mathbf{m m}]}\end{array}$ & $\begin{array}{c}\text { No. of teeth } \\
{[\mathbf{m m}]}\end{array}$ & $\begin{array}{c}\text { Max. cutting depth } \\
{[\mathbf{m m}]}\end{array}$ \\
\hline High-speed cutter & 36 & 4 & 2 \\
\hline Monolith cutter $\mathbf{\Phi 1 6}$ & 16 & 6 & 6 \\
\hline Monolith cutter $\boldsymbol{\Phi 8}$ & 8 & 4 & 4 \\
\hline Face cutter $\boldsymbol{\Phi} \mathbf{1 0 0}$ & 100 & 8 & 4 \\
\hline Face cutter $\boldsymbol{\Phi} \mathbf{4 0}$ & 40 & 4 & $5 \mathrm{D}$ \\
\hline Drill & 6.6 & - & \multicolumn{2}{|}{} \\
\hline
\end{tabular}



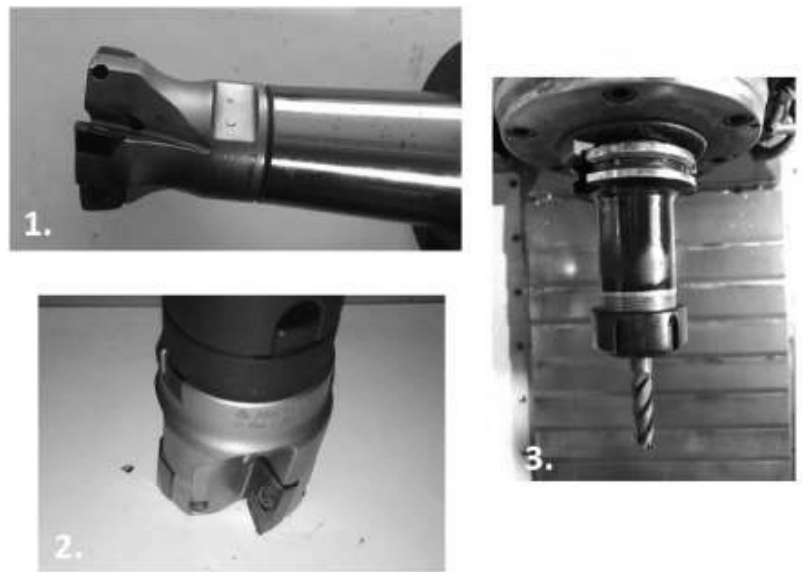

Figure 4. Tools used: 1. High feed cutter. 2. Face cutter. 3. Monolith cutter.

In the tools shown in Fig. 4, the cutting tool inserted and coatings used are given in the following table.

Table 3. Cutting materials and coatings.

\begin{tabular}{|l|c|c|c|}
\hline Cutting materials & Tungsten carbide & Cermet & Tungsten carbide \\
\hline Coating & $\mathrm{TiCN}$ & - & $\mathrm{TiN}+\mathrm{TiCN}+\mathrm{Al}_{2} \mathrm{O}_{3}$ \\
\hline Grade & $\mathrm{PC} 5300$ & $\mathrm{CN} 20$ & $\mathrm{PC} 5300$ \\
\hline $\begin{array}{l}\text { Recommended } \\
\text { cutting speed }[\mathbf{m} / \mathbf{m i n}]\end{array}$ & $100 \sim 150$ & $130 \sim 230$ & $100 \sim 150$ \\
\hline Producer & Korloy & Korloy & Korloy \\
\hline
\end{tabular}

Experiments aimed at the study of the topography of the machined surface are carried out on the part called robot track guide bar. This part is made from a blank (Fig. 5), whose dimensions are $310 \mathrm{~mm} \times 80 \mathrm{~mm}$ x $20 \mathrm{~mm}$ and it was cut by plasma. The following figure provides a preview of a real blank for producing a robot track guide bar.

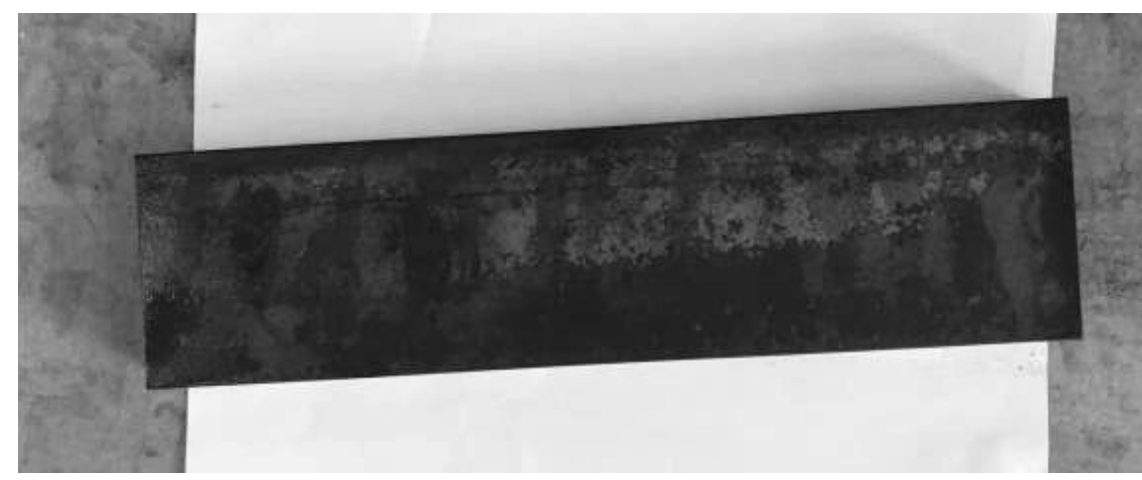

Figure 5. Blank of producing a robot track guide bar.

Before experimenting, a simulation method was applied to the research. Through the 3D CAD software a model of the subsequently manufactured part was made (Fig. 6). 


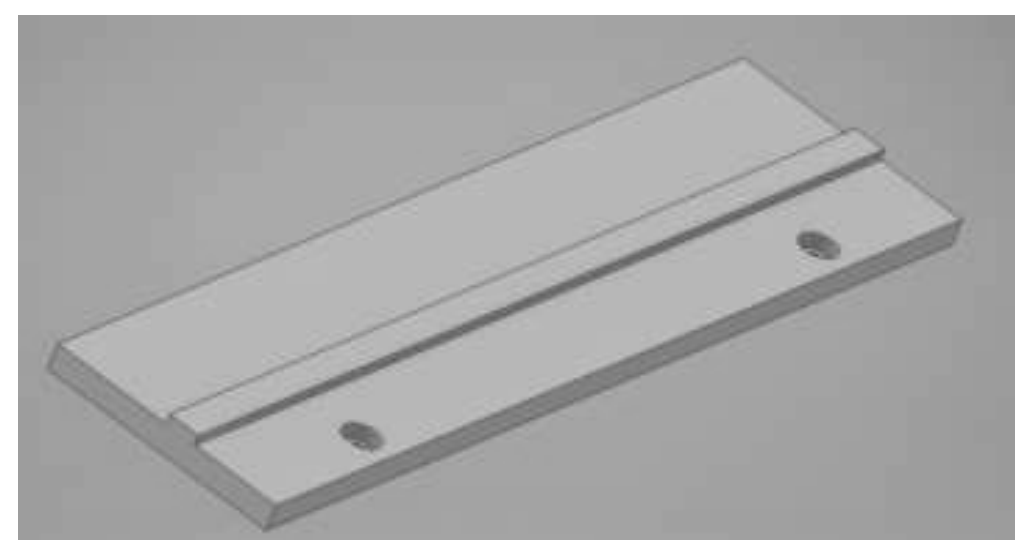

Figure 6. 3D model of the manufactured part.

\section{DESCRIPTION OF CONDUCTED EXPERIMENTS}

The experiments were carried out by milling technology using several milling cutters to create the required shapes and dimensions of the component and also to implement the helix strategy. A drill was used to form holes during the first clamping of the component.

Before performing the experiments, a simulation method was applied to define the tool paths and basic cutting parameters to ensure the desired shape of the manufactured part. A preview of applying the simulation method to research is presented below (Fig. 7).
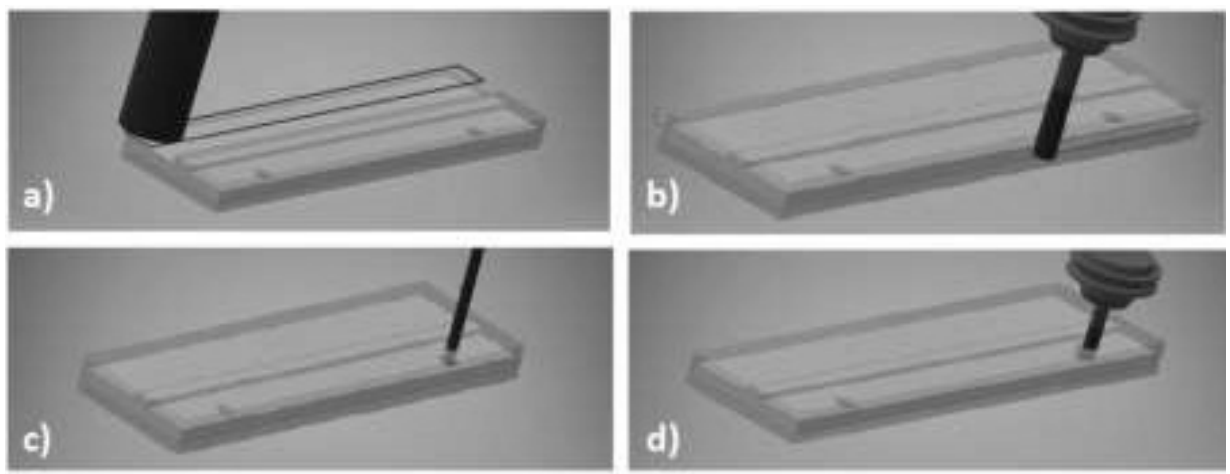

Figure 7. Illustration of applying the simulation method to research: a) simulation of roughing, b) simulation of contour smoothing, c) simulation of drilling, and d) simulation of milling of recesses.

During this investigation, 3 experiments were carried out (Fig. 8):

- $1^{\text {st }}$ experiment: machining of K100 with hardness HRC 60

- $2^{\text {nd }}$ experiment: machining of $100 \mathrm{CrMnMo} 7$ with hardness HRC 60

- $3^{\text {rd }}$ experiment: machining of $16 \mathrm{MnCr} 5$ with hardness HRC 60

The individual materials in the numbered experiments were machined in three different alternatives, during which the cutting speed varied. The cutting parameters (including cutting speed) were determined according to requirements from practice, recommended by the producer. Cutting parameter values for each of the alternatives are listed in the following tables. 
Table 4. Cutting parameters.

\begin{tabular}{|c|c|c|c|c|c|c|}
\hline \multicolumn{7}{|c|}{ 1st alternative } \\
\hline $\begin{array}{l}\text { operation / } \\
\text { parameter }\end{array}$ & $\begin{array}{l}\stackrel{00}{\Xi} \\
: 00 \\
0 \\
0 \\
0\end{array}$ & 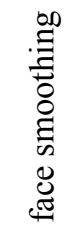 & 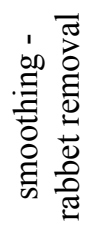 & 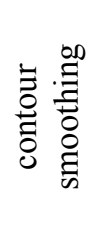 & 告 & 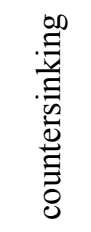 \\
\hline $\begin{array}{l}\text { Cutting speed } \\
{\left[\mathrm{m}_{\text {.min }}{ }^{-1}\right]}\end{array}$ & 170 & 140 & 140 & 140 & 70 & 140 \\
\hline $\begin{array}{l}\text { Travel speed } \\
{\left[\mathrm{mm} \mathrm{min}^{-1}\right]}\end{array}$ & 4000 & 400 & 400 & 835 & 675 & 668 \\
\hline $\begin{array}{c}\text { Cutting depth } \\
{[\mathrm{mm}]}\end{array}$ & 0.5 & 0.5 & 0.5 & 0.5 & 8 & 1 \\
\hline $\begin{array}{c}\text { Spindle speed } \\
\text { [RPM] }\end{array}$ & 1353 & 454 & 1111 & 2787 & 3377 & 5573 \\
\hline $\begin{array}{c}\text { Feed per tooth } \\
{[\mathrm{mm}]}\end{array}$ & 0.7 & 0.11 & 0.09 & 0.05 & 0.1 & 0.03 \\
\hline \multicolumn{7}{|c|}{ 2nd alternative } \\
\hline $\begin{array}{c}\text { Cutting speed } \\
{\left[{\left.\mathrm{m} . \mathrm{min}^{-1}\right]}^{-1}\right.}\end{array}$ & 150 & 120 & 120 & 120 & 70 & 120 \\
\hline $\begin{array}{l}\text { Travel speed } \\
{\left[\mathrm{mm}_{\mathrm{min}} \mathrm{min}^{-1}\right]}\end{array}$ & 5000 & 350 & 350 & 710 & 675 & 573 \\
\hline $\begin{array}{c}\text { Cutting depth } \\
{[\mathrm{mm}]}\end{array}$ & 0.5 & 0.5 & 0.5 & 0.5 & 8 & 1 \\
\hline $\begin{array}{c}\text { Spindle speed } \\
\text { [RPM] }\end{array}$ & 1194 & 397 & 972 & 2388 & 3377 & 4777 \\
\hline $\begin{array}{c}\text { Feed per tooth } \\
\text { [mm] }\end{array}$ & 1.05 & 0.11 & 0.09 & 0.05 & 0.1 & 0.03 \\
\hline \multicolumn{7}{|c|}{ 3rd alternative } \\
\hline $\begin{array}{l}\text { Cutting speed } \\
{\left[\mathrm{m}_{\mathrm{min}} \mathrm{min}^{-1}\right]}\end{array}$ & 130 & 100 & 100 & 100 & 70 & 100 \\
\hline $\begin{array}{l}\text { Travel speed } \\
{\left[\mathrm{mm} \cdot \mathrm{min}^{-1}\right]}\end{array}$ & 6000 & 270 & 270 & 600 & 675 & 477 \\
\hline $\begin{array}{c}\text { Cutting depth } \\
{[\mathrm{mm}]}\end{array}$ & 0.5 & 0.5 & 0.5 & 0.5 & 8 & 1 \\
\hline $\begin{array}{c}\text { Spindle speed } \\
\text { [RPM] }\end{array}$ & 1035 & 306 & 750 & 1990 & 3377 & 3980 \\
\hline $\begin{array}{c}\text { Feed per tooth } \\
{[\mathrm{mm}]}\end{array}$ & 1.5 & 0.11 & 0.09 & 0.05 & 0.1 & 0.03 \\
\hline
\end{tabular}




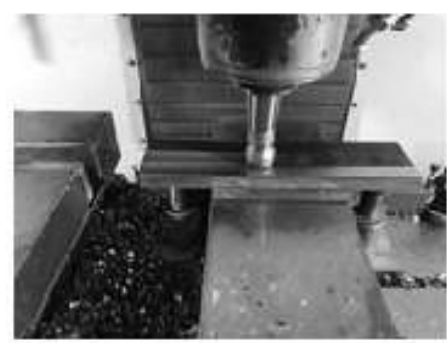

a)

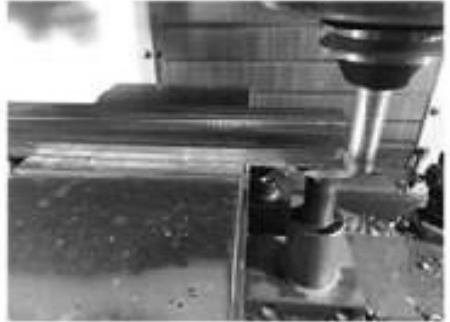

b)

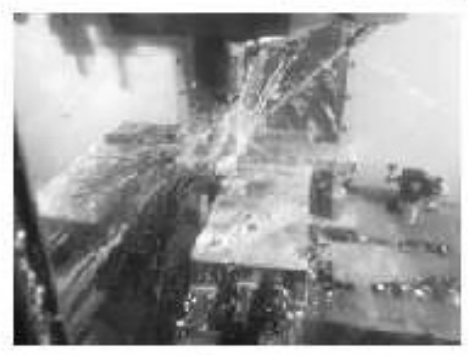

c)

Figure 8. Illustration of the $1^{\text {st }}$ experiment: a) roughing of the face surface of the work-piece, b) contour milling, and c) smoothing of work-piece.

\section{RESULTS AND DISCUSSION}

To evaluate the time-effectiveness of the manufacturing process, the total machining time, which consisted of basic machine time and also auxiliary times, was determined. Auxiliary times are the sum of the times needed for loading and unloading of the workpiece, tool replacement, and so on. Auxiliary times were measured during experiments using stopwatches. The total production time for a one-piece component is given in the following table.

Table 5. Total production time for a one-piece component.

\begin{tabular}{|c|c|}
\hline Alternatives & Time $\boldsymbol{\tau}_{\mathbf{s}}$ [min] \\
\hline $\mathbf{1}^{\text {st }}$ alternative & 21.28 \\
\hline $\mathbf{2}^{\text {nd }}$ alternative & 21.30 \\
\hline $\mathbf{3}^{\text {rd }}$ alternative & 22.98 \\
\hline
\end{tabular}

Due to the requirements of practice, a one-piece component must be produced within a time limit of 23 minutes to ensure time efficiency. All considered alternatives meet this requirement.

With respect to the subject of the research, the machined surface roughness of the components was subsequently assessed. The roughness was measured using Handysurf E-35A with a standard sensor and a diamond measuring tip. The following table lists the average values of measured roughness in individual alternatives for selected cutting materials. 
Table 6. Determination of roughness.

\begin{tabular}{|c|c|c|c|}
\hline Experiment & Alternative & Operation & Roughness $\operatorname{Ra}[\mu \mathrm{m}]$ \\
\hline \multirow{6}{*}{1} & \multirow{2}{*}{1} & Roughing & 6.2 \\
\hline & & Smoothing & 1.3 \\
\hline & \multirow{2}{*}{2} & Roughing & 6.1 \\
\hline & & Smoothing & 1.1 \\
\hline & \multirow{2}{*}{3} & Roughing & 6.0 \\
\hline & & Smoothing & 0.8 \\
\hline \multirow{6}{*}{2} & \multirow{2}{*}{1} & Roughing & 5.8 \\
\hline & & Smoothing & 0.7 \\
\hline & \multirow{2}{*}{2} & Roughing & 5.9 \\
\hline & & Smoothing & 0.7 \\
\hline & \multirow{2}{*}{3} & Roughing & 5.9 \\
\hline & & Smoothing & 0.6 \\
\hline \multirow{6}{*}{3} & \multirow{2}{*}{1} & Roughing & 5.7 \\
\hline & & Smoothing & 0.6 \\
\hline & \multirow{2}{*}{2} & Roughing & 5.7 \\
\hline & & Smoothing & 0.7 \\
\hline & \multirow{2}{*}{3} & Roughing & 5.9 \\
\hline & & Smoothing & 0.5 \\
\hline
\end{tabular}

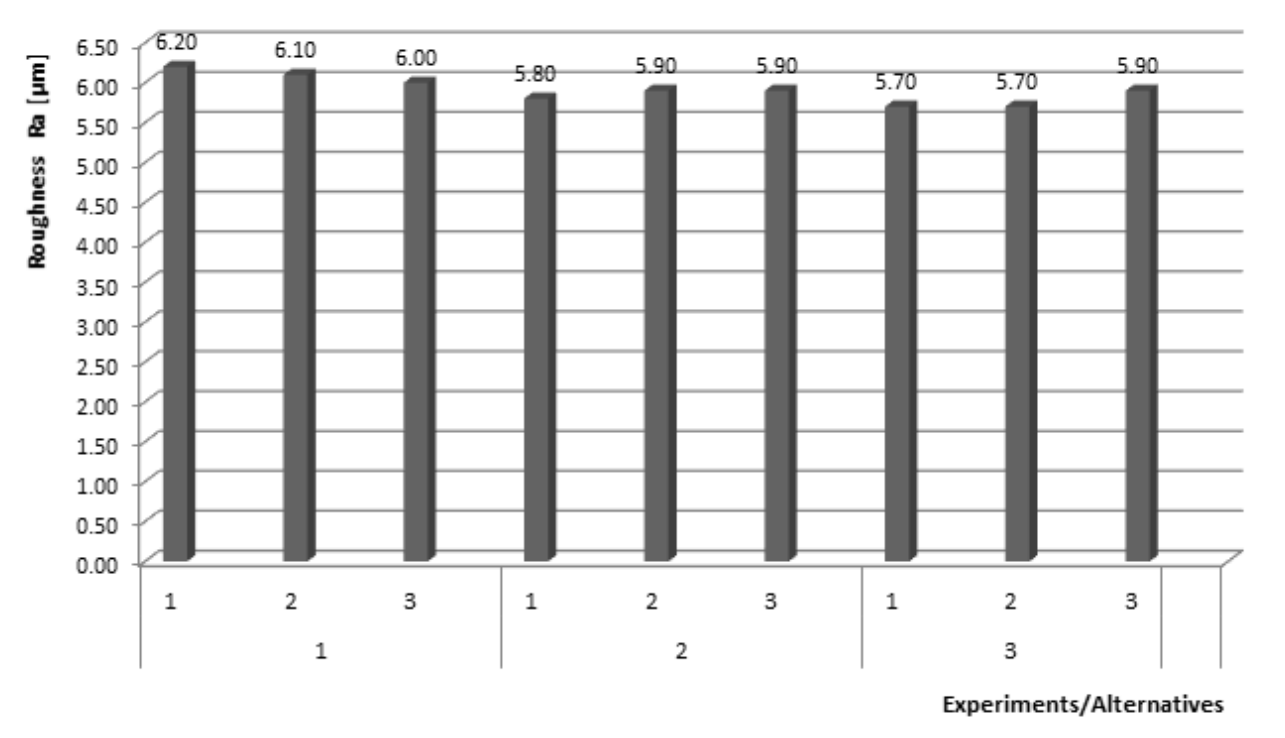

Figure 9. Diagram of roughness after the roughing. 
The above table and its first graphical interpretation show that the average value of the roughness achieved after roughing on the given surface of the machined parts was around $6 \mu \mathrm{m}$. The surface roughness requirements for roughing through the milling technology are set within the range of 6.3-25 $\mu \mathrm{m}$ in IT 10-13 and it can be concluded that the average values of the measured roughness after the roughing operations in the individual alternatives are generally satisfactory.

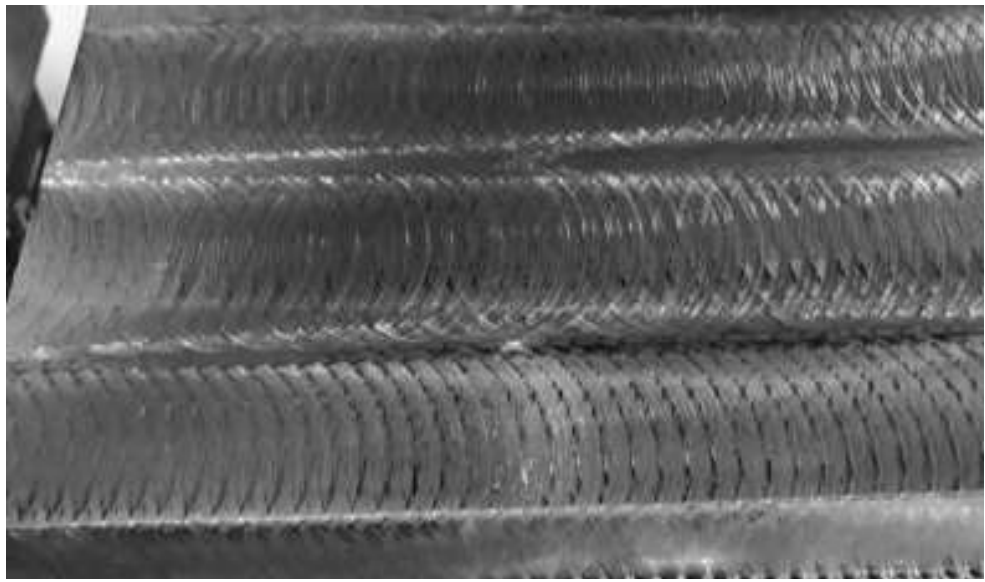

Figure 10. The roughness of surface after the roughing, experiment No. 1.

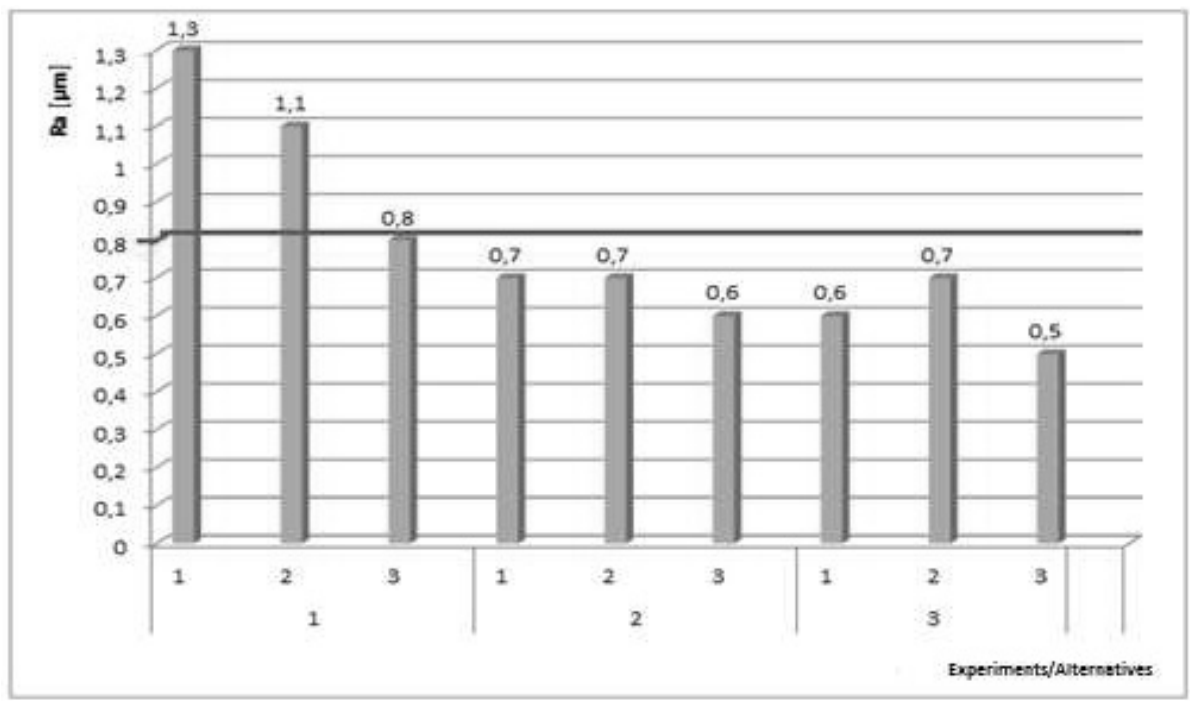

Figure 11. Diagram of roughness after the smoothing.

When assessing the roughness of the machined surface after smoothing, it is necessary to take into account the prescribed roughness of the drawing documentation. This prescribed roughness is set to $0.8 \mu \mathrm{m}$, which is indicated in the graphical interpretation by a red line. As clearly shown in the graph, the values when machining the tool steel K100 did not comply with this regulation in two cases. At higher speeds, the roughness values increased rapidly due to wear of the tool. At higher speeds, bevels have also been recorded due to pushing the milling cutter away at high cutting speed and large feeds. The required surface roughness value was only observed in the first experiment when performing the third alternative, during which the surface was machined at the cutting speed: $\mathrm{v}_{\mathrm{c}}=100 \mathrm{~m} \cdot \mathrm{min}^{-1}$. In all other experiments and alternatives, the final required roughness value was observed. 


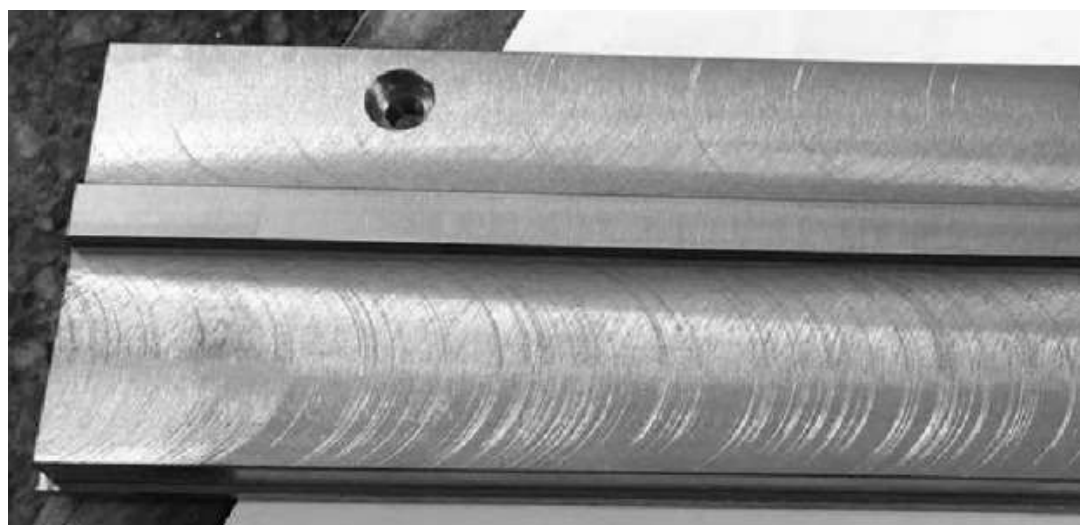

Figure 12. The roughness of surface after the smoothing, experiment No. 1, unobserved parameters.

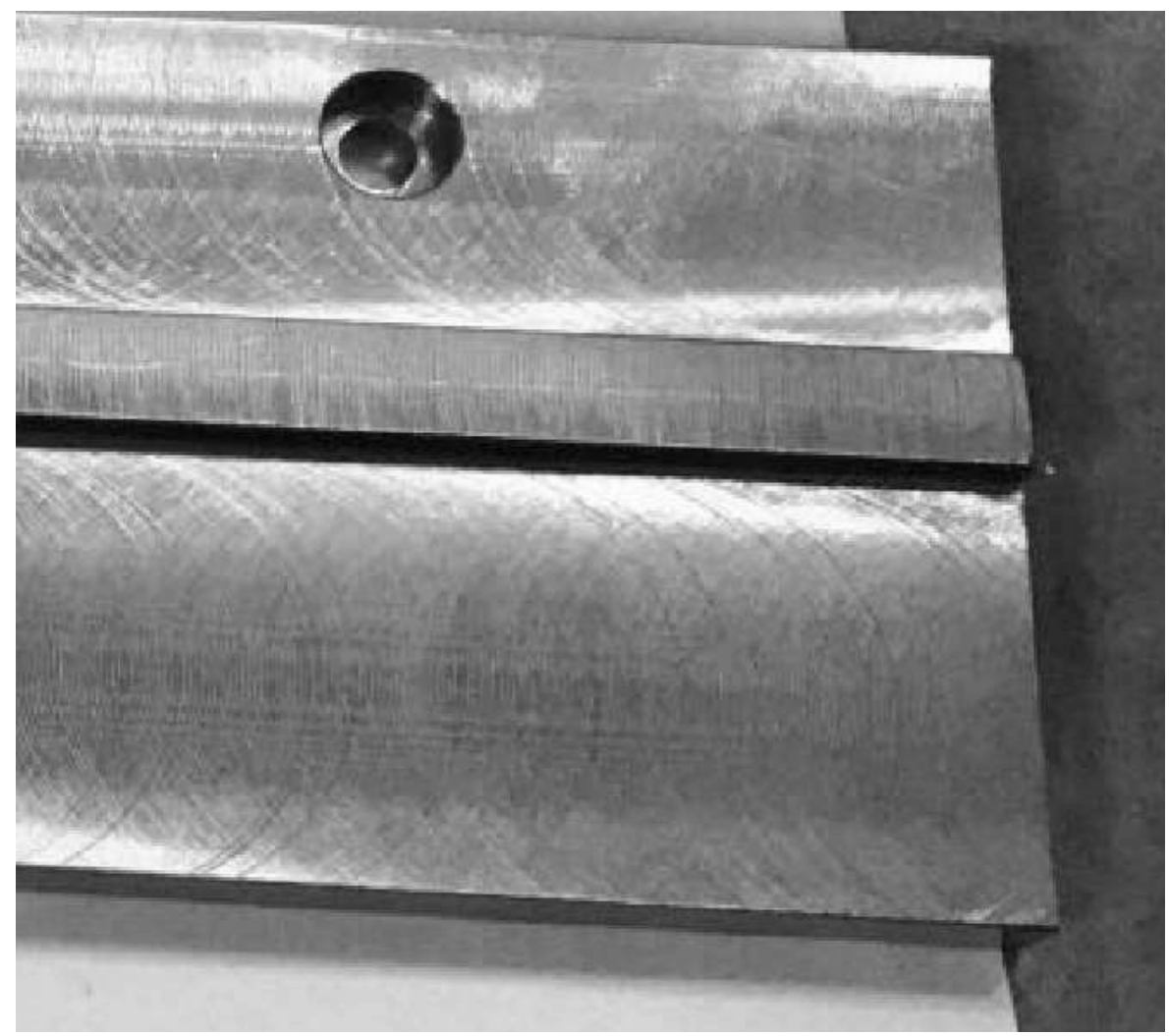

Figure 13. The roughness of surface after the smoothing, experiment No. 1, observed parameters.

In the experiments, 2,000 pieces were produced for each of the alternatives. The number of functionally machined parts is shown in the following table (Table 7).

Due to the fact that machining of superhard cutting materials negatively influences the durability (cutting time required to reach the tool life criterion of cutting tools), this factor has also been assessed during the experiments. The tools by which superhard materials are machined are destroyed much earlier than when they are used for machining of classical materials. 
Table 7. The number of functionally machined parts.

\begin{tabular}{|c|c|c|}
\hline Experiment & Alternative & $\begin{array}{c}\text { The number of functionally } \\
\text { machined parts }\end{array}$ \\
\hline \multirow{3}{*}{$\mathbf{1}$} & 1 & 19 \\
\cline { 2 - 3 } & 2 & 18 \\
\cline { 2 - 3 } & 3 & 21 \\
\hline \multirow{3}{*}{2} & 1 & 65 \\
\cline { 2 - 3 } & 2 & 59 \\
\cline { 2 - 3 } & 3 & 55 \\
\cline { 2 - 3 } & 1 & 58 \\
\cline { 2 - 3 } & 2 & 61 \\
\hline \multirow{3}{*}{3} & 3 & 59 \\
\hline
\end{tabular}

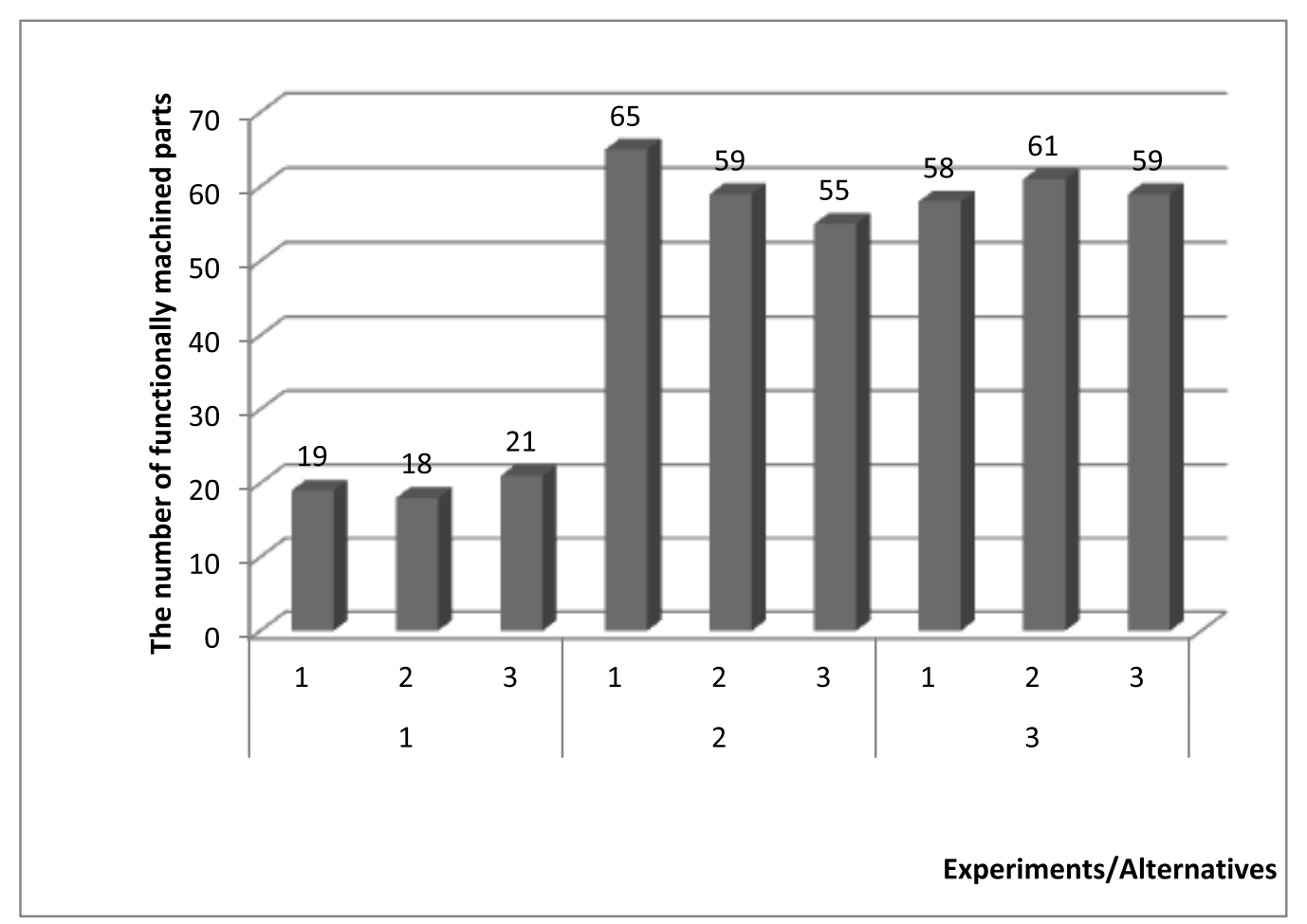

Figure 14. Diagram of a number of functionally machined parts.

On graphical interpretation, it is clear that the number of functionally machined pieces of K100 tool steel is significantly lower than for other materials. Since it is a super hard, hard-to-machine material, tool wear is much higher. An overview of the durability for individual tools and machining of the materials is given in Table 8 . 
Table 8. The durability of cutting materials, experiment No. 1.

\begin{tabular}{|l|c|c|c|}
\hline \multirow{4}{*}{ Operation } & Alternative & $\begin{array}{c}\text { Time } \\
\text { [min] }\end{array}$ & $\begin{array}{c}\text { Durability } \\
\text { [min] }\end{array}$ \\
\hline \multirow{4}{*}{ Foughing } & 1 & 8.52 & 161.88 \\
\cline { 2 - 4 } & 2 & 6.82 & 122.76 \\
\cline { 2 - 4 } & 3 & 5.67 & 119.07 \\
\hline \multirow{3}{*}{ Smoothing-rabbet removal } & 1 & 1.54 & 29.26 \\
\cline { 2 - 4 } & 2 & 1.74 & 31.32 \\
\cline { 2 - 4 } & 3 & 2.28 & 47.88 \\
\cline { 2 - 4 } & 2 & 1.56 & 29.64 \\
\hline \multirow{3}{*}{ Contour smoothing } & 3 & 1.78 & 32.04 \\
\cline { 2 - 4 } & 1 & 7.52 & 142.88 \\
\cline { 2 - 4 } & 2 & 8.78 & 158.04 \\
\cline { 2 - 4 } & 3 & 10.53 & 221.13 \\
\hline
\end{tabular}

During the realization of the first experiment, the durability of the fast-moving cutter used for roughing operations ranged from 119.07 to $161.88 \mathrm{~min}$. with respect to cutting speed and number of functionally machined parts. Tools and cutting materials for surface finishing and removal have considerably shorter durability since they need to be replaced after about 30 minutes. The monolithic contour cutter had an interchange interval from $142.88 \mathrm{~min}$. to $221.13 \mathrm{~min}$. when performing individual experiments.

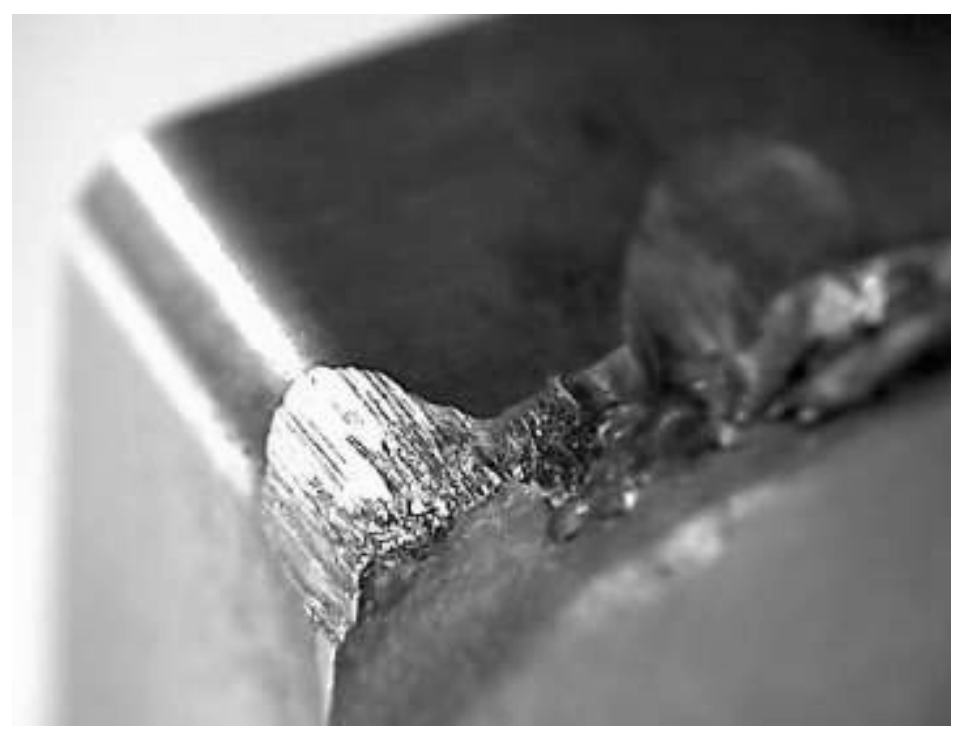

Figure 15. Wear of cutting tool inserting face milling cutter. 
Table 9. The durability of cutting materials, experiment No. 2 .

\begin{tabular}{|l|c|c|c|}
\hline \multirow{3}{*}{ Operation } & Alternative & $\begin{array}{c}\text { Time } \\
\text { [min] }\end{array}$ & $\begin{array}{c}\text { Durability } \\
\text { [min] }\end{array}$ \\
\hline \multirow{3}{*}{ Roughing } & 1 & 8.52 & 553.8 \\
\cline { 2 - 4 } & 2 & 6.82 & 402.38 \\
\cline { 2 - 4 } & 3 & 5.67 & 311.85 \\
\hline \multirow{3}{*}{ Face smoothing } & 1 & 1.54 & 100.1 \\
\cline { 2 - 4 } & 2 & 1.74 & 102.66 \\
\cline { 2 - 4 } & 3 & 2.28 & 125.4 \\
\hline \multirow{3}{*}{ Contour smoothing } & 1 & 1.56 & 101.4 \\
\cline { 2 - 4 } & 2 & 1.78 & 105.02 \\
\cline { 2 - 4 } & 3 & 2.32 & 127.6 \\
\cline { 2 - 4 } & 3 & 7.52 & 488.8 \\
\hline & & 8.78 & 518.02 \\
\hline
\end{tabular}

During the machining of the second material, compared with the first one, there is a significantly higher durability of selected cutting tools and materials in the individual alternatives, because of other properties of the material and its easier machining. Results of this experiment are presented in Table 9.

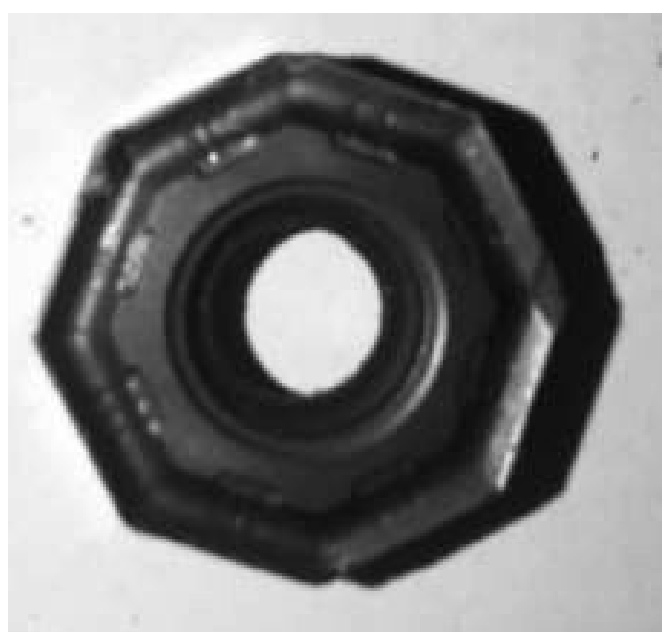

Figure 16. Wear of cutting tool inserting smoothing milling cutter. 
Table 10. The durability of cutting materials, experiment No. 3 .

\begin{tabular}{|l|c|c|c|}
\hline \multirow{3}{*}{ Operation } & Alternative & $\begin{array}{c}\text { Time } \\
\text { [min] }\end{array}$ & $\begin{array}{c}\text { Durability } \\
\text { [min] }\end{array}$ \\
\hline \multirow{3}{*}{ Roughing } & 1 & 8.52 & 494.16 \\
\cline { 2 - 4 } & 2 & 6.82 & 416.02 \\
\cline { 2 - 4 } & 3 & 5.67 & 334.53 \\
\hline \multirow{3}{*}{ Face smoothing } & 1 & 1.54 & 89.32 \\
\cline { 2 - 4 } & 2 & 1.74 & 106.14 \\
\cline { 2 - 4 } & 3 & 2.28 & 134.52 \\
\hline \multirow{3}{*}{ Smoothing-rabbet removal } & 1 & 1.56 & 90.48 \\
\cline { 2 - 4 } & 2 & 1.78 & 108.58 \\
\cline { 2 - 4 } & 3 & 2.32 & 136.88 \\
\hline \multirow{3}{*}{ Contour smoothing } & 1 & 7.52 & 436.16 \\
\cline { 2 - 4 } & 2 & 8.78 & 535.58 \\
\cline { 2 - 4 } & 3 & 10.53 & 621.27 \\
\hline
\end{tabular}

The durability of tools and cutting materials during machining of the material in the third experiment is similar to that of the material used in the second experiment. Results of this experiment are presented in Table 10. Durability values range from $89.32 \mathrm{~min}$. up to $621.27 \mathrm{~min}$.

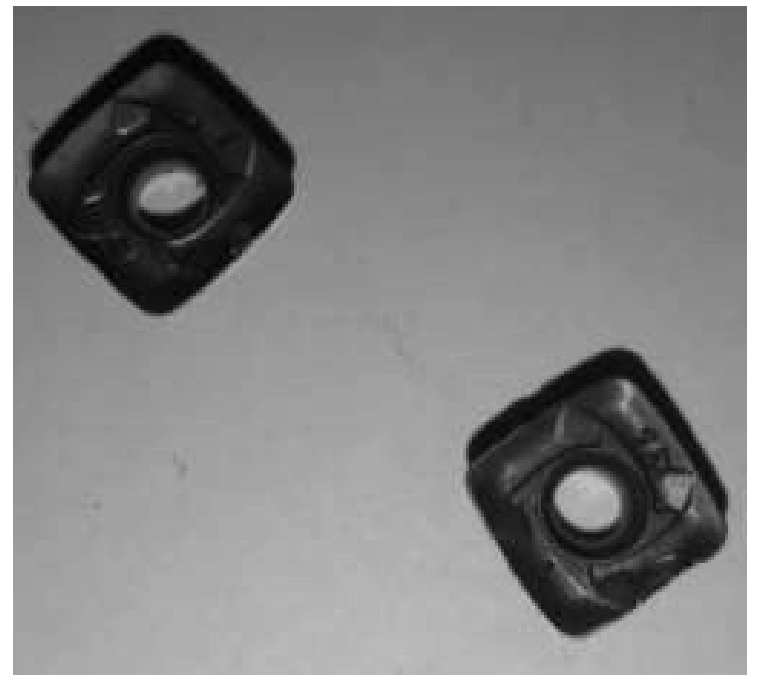

Figure 17. Wear of cutting tool insert - high feed milling cutter. 


\section{CONCLUSION}

Many factors influence the quality of the machined surface. Global optimization of the production process to achieve the same output is impossible. Selected technical materials that have been the subject of experiments are used as materials for the production of gear parts of driving or driven elements, abrasion-resistant elements of highstrength components of equipment, or the structural parts of fixtures in the automotive and robotic industries. Their properties determine their majority use. Improving these materials by the hardening process and increasing their overall hardness results in worse machinability and achievement of surface $\mathrm{Ra}<0.6 \mu \mathrm{m}$ without the use of grinding. Examination of machinability and consequent impacts on surface quality and topography of the machined surface has undoubted importance in the manufacturing process for better knowledge of the properties of hardened materials. The machinability itself greatly influences the efficiency and economy of the production process and affects a variety of factors.

From the overall technical evaluation, it can be concluded:

1) the worst values are obtained from the experimental material No. 1-K100 with hardness HRC60 from the point of view of the primary parameter observed roughness of the surface;

2) when changing the cutting parameters in the individual alternatives, material K100 did not even achieve the prescribed roughness value in the production drawn in the two cases;

3) when evaluating the number of functionally machined pieces, the worst set material was again K100 tool steel;

4) the number of pieces machined from material K100 accounted for approximately one-third of the number of pieces of other materials that were machined in the other experiments.

Based on these findings and assessments, it can be concluded that the machining of superhard materials is difficult. In particular, machining of tool steels and other superhard materials requires special cutting tools, machines, and the use of progressive technologies to ensure the production of a dimensionally and qualitatively shaped functional component.

\section{ACKNOWLEDGMENT}

This work was supported by Scientific Grant Agency of the Ministry of Education, Science, Research and Sport of the Slovak Republic-VEGA 1/0080/20 and KEGA 014TUKE-4/2020. This work was supported by the Slovak Research and Development Agency under the contract No. APVV-15-0700.

\section{REFERENCES}

Agrawal, A., Goel, S., Rashid, W.B. \& Price, M. 2015. Prediction of surface roughness during hard turning of AISI 4340 steel (69 HRC). Applied Soft Computing, 30: 279-286.

Aouici, H., Fnides, B., Elbah, M., Benlahmidi, S., Bensouilah, H. \& Yallese, M. 2016. Surface roughness evaluation of various cutting materials in hard turning of AISI H11. International Journal of Industrial Engineering Computations, 7: $339-352$.

Aouici, H., Yallese, M.A., Fnides, B., Chaoui, K. \& Mabrouki, T. 2011. Modeling and optimization of hard turning of X38CrMoV5-1 steel with CBN tool: Machining parameters effects on flank wear and surface roughness. Journal of Mechanical Science and Technology, 25(11): 2843-2851.

Benardos, P.G. \& Vosnaikos, G.C. 2003. Predicting surface roughness in machining: A review. International Journal of Machine Tools and Manufacture, 43: 833-844.

Čepová, L., Šoková, D., Malotová, Š., Gapinski, B. \& Čep, R. 2016. Evaluation of cutting forces and surface roughness after machining of selected materials. Manufacturing Technology, 16(1): 45-48. 
Elmunafi, M.H.S., Yusof, N.M. \& Kurniawan, D. 2015. Effect of cutting speed and feed in turning hardened stainless steel using coated carbide cutting tool under minimum quantity lubrication using castor oil. Advances in Mechanical Engineering, 7 (8): 1-7.

Ferreira, R., Řehoř, J., Lauro, C.H., Carou, D. \& Davim, J.P. 2016. Analysis of the hard turning of AISI H13 steel with ceramic tools based on tool geometry: surface roughness, tool wear, and their relation. Journal of the Brazilian Society of Mechanical Sciences and Engineering, 38(8): 2413-2420.

Hassanpour, H., Sadeghi, M.H., Rasti, A. \& Shajari, S. 2016. Investigation of surface roughness, microhardness and white layer thickness in hard milling of AISI 4340 using minimum quantity lubrication. Journal of Cleaner Production, 120: 124-134.

Hassanpour, H., Sadeghi, M.H., Rezaei, H. \& Rasti, A. 2016. Experimental study of cutting force, microhardness, surface roughness, and burr size on micro milling of Ti6Al4V in minimum quantity lubrication. Materials and Manufacturing Processes, 31(13): 1654-1662.

ISO 4287:1997 Geometrical Product Specifications (GPS). Surface texture: Profile method - Terms, definitions and surface texture parameters.

Khamel, S., Ouelaa, N. \& Bouacha, K. 2012. Analysis and prediction of tool wear, surface roughness and cutting forces in hard turning with CBN tool. Journal of Mechanical Science and Technology, 26(11): 3605-3616.

Knapčíková, L. 2013. Examination of the surface of composite materials by atomic force microscopy. Strojárstvo, 17(12): 58-59.

Knežo, D., Andrejiová, M., Kimáková, Z. \& Radchenko, S. 2016. Determining of the Optimal Device Lifetime using Mathematical Renewal Models. TEM Journal, 5(2): 121-125.

Krolczyk, G.M., Krolczyk, J.B., Maruda, R.W., Legutko, S. \& Tomaszewski, M. 2016. Metrological changes in surface morphology of high-strength steels in manufacturing processes. Measurement, 88: 176-185.

Lehocká, D., Klichová, D., Foldyna, J., Hloch, S., Hvizdoš, P., Fides, M. \& Botko, F. 2017. Comparison of the influence of acoustically enhanced pulsating water jet on selected surface integrity characteristics of CW004A copper and CW614N brass. Measurement, 110: 230-238.

Michalik, P., Zajac, J., Fabianova, J. \& Mital, D. 2017. The study of the surface quality of the thin wall bearing units to rolls roller seats pipe conveyor. Advances in Science and Technology, 11(2): 192-197.

Mital'ová, Z., Mital', D. \& Botko, F. 2016. Measuring of roughness and roundness parameters after turning of composite material with natural reinforcement. Science report: Project CIII - PL-0007: Research on modern systems for manufacture and measurement of components of machines and devices. Kielce: Wydawnictwo Politechniki Świętokrzyskiej, 49-58.

Rashid, W.B., Goel, S., Davim, J.P. \& Joshi, S.N. 2016. Parametric design optimization of hard turning of AISI 4340 steel (69 HRC). The International Journal of Advanced Manufacturing Technology, 82(1-4): 451-462.

Sharma, R., Bansal, V. \& Chhabra, N. 2015. Effect of Cutting Parameter on Hard Turning by using Different Lubricating Condition. International Journal of Engineering Trends and Technology, 30(2): 75-82.

Ståhl, J.E., Schultheiss, F. \& Hägglund, S. 2011. Analytical and Experimental Determination of the Ra Surface Roughness during Turning. Procedia Engineering, 19: 349-356.

Valíček, J., Harničárová, M., Panda, A., Hlavatý, I., Kušnerová, M., Tozan, H., Yagimli, M. \& Václavík, V. 2016. Mechanism of creating the topography of an abrasive waterjet cut surface. Machining, Joining and Modifications of Advanced Materials, 61: $111-120$. 